\title{
System of education and value orientations of youth
}

\author{
Natalia L. Smakotina ${ }^{1, *}$, and Olga Yu.Kornienko ${ }^{1}$ \\ ${ }^{1}$ Lomonosov Moscow State University, Department of Global Studies, 119991, Moscow, Russia
}

\begin{abstract}
The paper is devoted to modernization of education. The modern education system, her influence on value orientations of youth in new conditions of development of information technologies, transition to the market relations, and mechanism of impact on formation and transformation of value orientations is considered. The comparative analysis of structure of value orientations of school students and students, in the conditions of continuous changes in education for the last decades is given, change of value orientations in the course of socialization of youth is traced on this basis.
\end{abstract}

\section{Introductory notes}

At the turn of XX and XXI century rapid development of communication systems, information technologies, the latest methods of knowledge transfer has led mankind to the transition from industrial society to information society, "knowledge society". The UNESCO defines XXI century as "the century of education" [1].

It means that the system of education constitutes the basis for the upbringing of actors of the future information society. It defined the vector of main education reforms in the modern education system, which stipulates the following important issues: decentralization and democratization, higher autonomy of education institutions together with greater public accountability, transfer to market-oriented models of their organization, management and financing [2].

The major approach to education in developed countries has become the education democratization which is manifested in many different structural elements, forms and ways. It includes the following: pupils' and students' self-management; public involvement in the process of defining the content and types of management in education institutions; creation of comprehensive schooling which is obligatory and open to everybody; greater possibilities to get higher education available not only to middle-class but also to lower layers of society; rejection of academism and a turn from former system of education based on knowledge transfer to mastering the search methods of information.

\section{Permanent modernization of education}

The post-soviet Russia experienced the transition to an open society, to new social-economic environment which put forward the necessity to create an adequate education media and a new education system.

Starting at the 1990s the demand for reforming and modernizing an education system became a necessity with the target of improving the quality of education. This demand is still of great importance today, but the difference of it from reforms in the previous period is an urgent necessity to adjust the education system to the public tasks in the sphere of economy, politics and sociocultural relations which are shaped in accordance with today's needs.

New demands for the quality of education put forward the tasks of streamlining education, teaching methods and upbringing towards the new goals in the development of the country. Among the factors, that are now defining the development and the state of current education, the scientific dispute plays a crucial role, handling the place of historical, cultural and moral values, together with the déideologization of education, history of Russia and the expansion of electronic means to form a sophisticated structure of the education communication system. A new important stage in reforming the education system was connected with a fundamental legal provision, namely, the Federal Law on Education in RF which came into force on the $10^{\text {th }}$ of June, 1992 [3]. The law set general rules and principles to regulate all types of legal relations in the system of education which can arise among the stakeholders of the education system.

An outstanding feature of the society in the $21^{\text {st }}$ century is its dynamics, social uncertainty and instability. And at this period the government introduced a new bunch of transformations into the education system under the name of "The Concept of Modernization of the Russian Education for the period till 2010". It was officially approved on the $29^{\text {th }}$ of December, 2001 and set new orientations for the education policy [4]. The main mechanisms granting an available education of high quality included the

\footnotetext{
Corresponding author: smakotina@mail.ru
} 
introduction of the Unified State Exam (USE) and the per capita public funding in education. The other milestone in the modernization of education was Russia's signature of the Bologna Process in 2003.It allowed Russia to join the European countries and to participate in the formation of the European Higher Education Area. Nowadays education is more and more global, which implies that it is in the English language, uses Internet technologies and is market-oriented. As a result, many countries feel endangered, China being one of them.

Chinese people are no longer fascinated by globalization and the most outstanding evidence is the movement for protection of cultural and linguistic heritage. It is now fully appreciated that information dominance of the USA threatens cultural diversity. China has developed a very interesting approach to handling economic success and identity. Their idea is that economic success helps to strengthen the national identity, while the identity evolution contributes to economic success. An interesting example illustrates this phenomenon: in December 2010 China turned out to be economy number two and in some days there was introduced a ban on Americanisms in Chinese mass media. There were undertaken some other state strategic measures to support Chinese culture, to promote cultural diversity both by involvement of people and the main national communities [5]. The most striking examples include the events of the Cultural Heritage Days and the introduction of a new system of the Chinese characters. Some other measures were undertaken to strengthen the national identity and were under the control of country leaders. These measures include: monitoring of Internet space in the framework of the Golden Shield Project (Great Firewall of China), regular censorship of Chinese TV media, the latter being the most popular and available information outlet. This control is very effective as, contrary to other countries, Chinese mass media is managed and controlled by the state.

China has gone a long way while choosing between three options in its development: West-orientation, nationalism and self-strengthening [6]. The selfstrengthening supporters call for preservation of Chinese heritage while adapting all essential things from the West to Chinese life and education. Everything is done in order to preserve the Chinese cultural identity in all fields, especially in education, and to borrow from the West only scientific and technical innovations to enhance the power of the state.

The situation is quite different in India where the progress is associated with Americanization which is quite alarming for the population. The situation is aggravated by the thing that though the number of official languages is quite outstanding in India but the state languagesare only Hindi and English. The Indian society before the globalization era believed that the language is the key to education. Education itself mean the key to knowledge and spiritual wealth. Besides, for many centuries the "brain drain" was detested while now it is believed to be a sign of success. The English language has penetrated into such important spheres as education (it is up to parents to choose whether a child will study English or Indian language), information sphere (Internet, mass media, telecommunication), business and science. The situation with methods of teaching is also a depressive one. Earlier, the accent was on studying English literature and culture, while now the priority shifts towards the requirement of being understood in the process of communication and to obtain information. And what is more, the same approach is used in teaching native languages.

As for Russia, it appreciated the advantages and threats of these global processes later than other countries. Now the processes are speeding up and we cannot foresee future challenges. At the moment Russia does not have a strategy of integration into a global cultural environment and we are quite vulnerable to Western influence which is especially evident in the following spheres:

a) the English language has penetrated into many communication segments and sometimes the Russian speech sounds like the one of the aliens: "cost-cutting, outsourcing, perception, leverage, leasing etc." Of course, new words often come together with new notions, but some of these notions can be easily interpreted into Russian. For example, "Capital" by K. Marx was translated into Russian without any loan translation. Besides, language becomes unclear, by drawing up USE formulations are given by supply of material on "foreign" logic.

b) Anglo-American methods of teaching are introduced into the Russian education system and the education process in Russia as well as in India has undergone transformations from being a culturalanalytical one to the process of information search which is not typical of the Russian social media. However, the approach becomes more and more important for a success at the Unified State Exam.

c) We face up the hybridization of information environment and are under the pressure of commercials, translated from English; our mind is under the pressure of Americanized sitcoms, shows, soap-operas, quizzes, that are dragging us down to the alien information media.

d) The most dangerous is the fact that the collective way of Russian cultural environment destroyed by the power of individual success, is forced by money ideology, which greatly changes the value orientations of modern youth.

In fact, the transition to information society, social and economic changes, globalization processes cause the emergence of a great amount of factors which shape new value orientations of young people. And the first place in the evolution of this process belongs to education.

\section{Methodology}

The basic theory is the interpretation introduced by A.V. Yadov. It stipulates that the value orientations imply the highest level of the hierarchy of human predispositions responsible for perception of their living conditions and behavior in the long term perspective [7]. In the context of the theoretical approach the value orientations mean the criteria for making important decisions in situations 
of moral choice. And every individual acts, using the set of values typical of the society that he/she belongs to. In case of orientation towards some definite value or a group of values it means that an individual is placed within some meaningful level of a sophisticated system of value orientations.

The empirical basis of our practical analysis is founded on the results of the survey "Impact of modern education system on formation of value orientations among young people" which was conducted by Lomonosov Moscow State University. The target audience was 976 senior pupils and students at the age of 15-23 in 15 locations on the territory of 5 Russian regions. It was based on a representative sample by gender, education, place of residence. The surveys were conducted on the following territories: the Central Russia, the South, the Urals, Moscow and St. Petersburg. They were based on the same approaches as the allRussia research "Social Potential of Youth" conducted in 2010-2012 in 62 localities of 15 regions in Russian Federation. The latter was conducted among 1476 people at the age of 15-29 years. Both surveys were guided by prof. N.L. Smakotina

\section{The Hierarchical Structure of Youth Values}

Modern hierarchy of youth values includes the following ones: health, family, job, friends, morals, entertainment, status, professionalism (Table 1)

Table 1. Value orientations of young people (\%)

\begin{tabular}{|l|c|r|}
\hline & Options & $\begin{array}{c}\% \\
\text { surveyed }\end{array}$ \\
\hline 1 & Health & 58 \\
\hline 2 & Friends & 53 \\
\hline 3 & Family, children & 50 \\
\hline 4 & Love & 42 \\
\hline 5 & Self-realization & 34 \\
\hline 6 & Carrier & 32 \\
\hline 7 & Intellect & 29 \\
\hline 8 & Independence & 26 \\
\hline 9 & Confidence & 26 \\
\hline 10 & Beauty, being fit & 18 \\
\hline 11 & Stability & 17 \\
\hline 12 & Morals & 16 \\
\hline 13 & Status & 16 \\
\hline 14 & Energy, will, drive & 15 \\
\hline 15 & Professionalism & 13 \\
\hline 16 & Free time entertainment & 13 \\
\hline
\end{tabular}

The first thing to do while shaping some definite pattern of conduct in young people is to form the appropriate values which implies the significance of upbringing. Nowadays the system of upbringing in higher education is a topical one, having been absolutely neglected in the last twenty years. However, the problem is more on paper than in reality as it is quite formal and lacks interest.
Besides, the data points to the following: the respondents singled out as topical the moral $(77 \%)$ and patriotic $(11 \%)$ types of upbringing while the physical, aesthetic and labor types of education activity are marked much lower. The data testifies to the fact that the issues of morals and patriotism are urgent both for schools and higher education institutions.

Students connect meaning of life with future family and realization of their abilities.. The respondents demonstrate the desire to establish some basis for the future of their children and the generally adopted importance of the family institute. The present situation allows a great variety of education models and it is absolutely important to make a choice among them by assessing whether this or that type of education includes the upbringing components and whether it can form value orientations and Russian identity to shape future behavior, which is quite important for the professional sphere [8].

Unfortunately, the absence of a strategic approach to upbringing in the Russian education system leads to a greater popularity of entertainment values among the youth which are now substituting labor values. Young people imagine the Western life as enjoyment of material welfare and comforts without working hard.

Multiple surveys show that there is a stable trend among young people to prefer material goods to morals and identity. It resulted from transformation of major social institutes (family, education etc.) in the process of transition to the market economy and dramatically affected the basic orientations of the youth.

Now the most widely-spread value orientation is to be successful, to make a career (37\%), to become rich, to live the way you want it (20\%). It seems that only every seventh Muscovite strives for self-improvement and selfrealization (15\%). Altruism is popular among $7 \%$ or less of young Muscovites. About one third of young people think that the state must guarantee them social benefits, while another $33 \%$ of young people believe that a man must rely on himself/herself to ensure better old age. They try hard to earn as much money as possible to grant their wellbeing.

In general, young people over 20 who have a job and higher education are more oriented towards initiative and independent actions to ensure success and wellbeing than other groups of the youth. They favor stability and stand for moral principles. Besides, the whole state of cultural and moral potentials of young people point out to a greater appreciation by them of such target values as family, love, and carrier.

Temporary relevant values include wisdom, health, love, happy life, stability and friendly environment in the country and abroad.The instrumental values of students embraced the following top-ranked values: wellbreeding, humor, tolerance to opinions of other people, honesty and consideration.

Value orientations are quite changeable. Thus, about $94 \%$ of respondents said that their value orientations had turned out to be better in the course of the last 5 years (it corresponds approximately to the period of their university study), while only $4 \%$ of the respondents thought that nothing had changed. 
The majority of the respondents believe that the value orientations of young people should be inculcated through family upbringing while mass media impact being of minor importance [9].

According to the students, the system of education instills the value of the education itself $(71 \%)$, selfdevelopment $(60 \%)$ and career $(54 \%)$. The career value is looking more and more up because of the ambitions to be promoted. As for pupils, they want to enter a university or a college in order to find later a good job or to be promoted.

The way education has an impact on value orientations is manifested in the choice of concrete subjects which are responsible for their shift in the worldview or orientation values. The respondents give frequently the following answers:

- "I consider that, the general expansion of an outlook, acquaintance to many alternative points of view, meeting with interesting people have affected, but not some concrete objects. I have a right for an own way, a higher education institution only has helped me to realize it finally."

- "Thanks to history there was an interest in all subjects which result in the development of patience and diligence."

- "Anatomy. We will not live forever. We must value our and other people's lives."

- "Fundamental subjects (philosophy, concepts of modern science, history, scientific methodology) help to widen horizon. Professional subjects give an access to our future profession."

- "Many subjects are paid too much attention while some important professional subjects are shifted to the background."

- "The only change in my worldview, thanks to the university, is that we and our education are not important for anyone but ourselves."

One third of the students believe that history helps to understand better present day, about $20 \%$ regard history as a means of upbringing young generation. The youth, both in Europe and in Russia, think that the past is important for extending their horizons (49\%) and it is a source of knowledge about the history of the country $(40 \%)$.

What doesn't suit students in an education system? Students are quite often dissatisfied with an organization of a learning process, provision with literature ("insufficient number of copies", "few new books") and libraries' work. Besides, students think that practice and academic research work do not receive enough attention which is a challenge for all levels of education and more than $50 \%$ of the respondents said that the chances to find a job suiting their major is small and employment is not easy. But in general, the students think that education has had an impact on the value orientations. The most interesting answers are listed below:

- "The environment has shaped correct ideals and philosophy has given inspiration and taught true things."

- "Yes, it has influenced. The more educated is a person the bigger he thinks. I do think big."
- "The school and the university have shaped a greater part of my value orientations thanks to knowledge, independent analytical skills, a sense of camaraderie and fairness."

- "I have learnt how to adjust to complicated matters; the university has enlarged my worldview and circle of friends, so I have acquired a lot of new information (including the new values)"

Education in information society competes with other factors which also affect value orientation: the mass media and the Internet. Notwithstanding an age of young people, the Internet is mentioned as a priority.Nevertheless, students often use print mass media as they are taught to critically scrutinize the information to develop analytical skills and creative abilities.In general, schoolchildren use the Internet for getting information of all kinds $(47 \%)$, they combine information and communication (33\%), they are mainly interested in films and games $(9 \%)$. Students also use the Net mainly to search for information $(68 \%)$ and for socializing (32\%).

Schoolchildren widely use the Internet for socializing and watching films. Scientific and education interests take the third place while games are somewhere in the middle. Youth'problems, politics and economy are at the bottom. Students are, first of all, interested in education issues, and only then in entertainment and films. As for high school children, they are using the Web mainly to have fun, not to get new knowledge [10]. Among the most disturbing issues worth mentioning is the lack of practice and individual approach as well as a bad organization of leisure. The lack of practice can affect the job placement as there can be a gap between knowledge and its practical application.

Every third pupil believes that preparation for lessons takes a lot of time while every forth student marks, that he/she would prefer more professionally-oriented lessons and less lessons of general education subjects.

Nowadays the majority of schoolchildren have developed a negative attitude to the Unified State Exam and the State Final Examination (77\%). Their attitude was backed by the following arguments: "the exams do not check real knowledge", "the continuous assessment is not taken into account", "the world outlook is becoming dull", and "we are just coached for the examination tests". However, there were positive attitudes of schoolchildren who pointed out that "the exam makes the admission to the university easier", "there is a possibility to be ready for some definite format", and "the process of verification is unbiased as everything is checked by computers."

\section{Conclusion}

Today we see a trend to mergers and consolidations of institutions. Most students believe that the changes will not lead to the improvement of education and $76 \%$ of respondents developed a negative attitude towards the process. The students explained their attitude by the following statements: "it means a reduction of personnel", "the management of large associations works 
less efficiently", "it is aimed at ruining the Moscow education system", and "the addition of relevant disciplines is good." The main idea of this consolidation is to introduce cuts into the budget and is in pursue of purely economical aims, neglecting specific features of the educational process and it can affect the education quality or warp its content, shifting priorities towards commercial profits.

Thus, we can state that the last two decades have not led to transition of Russian education to the Bologna process as the quality of education is still an urgent problem; there is a discrepancy between the labor market demand for specialists and the system of training; education has changed its status, acquiring the status of a service sector.

It affected the attitude of young people towards education which is appreciated today as an instrumental value and not as the terminal value. Higher education is nowadays becoming some kind of a social lift and the modern youth represents a group with substantial social differentiation which is typical of any society. It is especially true for the society which has undergone a complicated period of transformations and it implies changes in value orientations.

\section{References}

1. UNESCO: Education. Available online: URL $\mathrm{http}: / /$ unesco.ru/ru/?module=news\&action $=$ theme \&i $\mathrm{d}=3$ (accessed on 20.03.2015).

2. V.M. Filippov, Reforms of education: Analytical review (CEP, Moscow, 2007) [In Rus]

3. Federal'nyi Zakon RF ot 10.07.92. N 3266-1 "Ob obrazovanii". Available online: URL: http://base.garant.ru/10164235/1/\#block_1\#ixzz 3aQvTt6rb (accessed on 01.03.2015) [In Rus]

4. Minobrazovaniya RF, prikaz ot 11.02.2002 N 393 "O kontseptsii modernizatsii rossiiskogo obrazovaniya na period do 2010 goda". Available online:URL:

http://www.zakonprost.ru/content/base/part/87209 (accessed on 10.03.2015) [In Rus]

5. V.A Abramov, Globaliziruyushchiisya Kitai: grani sotsiokul'turnogo izmereniya (Vostochnaya kniga, Moscow, 2010) [In Rus]

6. J.Wenshan, Identity and Contextual Construction, 341 (2010).

7. V.A. Yadov, Sotsiologicheskii zhurnal, 1, 35 (1994). [In Rus]

8. T.V.Naumenko, Credonew, 2, 9( 2013) [In Rus]

9. T.V.Naumenko, Credonew, 20, 27 (2000) [In Rus]

10. N. V.Mel'nikova, Vestnik Chelyabinskogo gosudarstvennogo pedagogicheskogo universiteta, 9, 314 (2011) [In Rus] 